\title{
Cerebrospinal Fluid Based Diagnosis in Alzheimer's Disease
}

\author{
Inga Zerr, Lisa Kaerst, Joanna Gawinecka and Daniela Varges \\ Dementia Research Unit, Dept. of Neurology, \\ Georg August University Göttingen
}

Germany

\section{Introduction}

The Alzheimer's disease (AD) is the most frequent form of dementia worldwide. The major neuropathological hallmarks of the disease are loss of neurons and synapse, senile plaques (extracellular aggregates primarily composed of $B$-amyloid; Aß) and neurofibrillary tangles (aggregates of hyperphosphorylated forms of the microtubule-associated tau protein) throughout cortical and limbic regions of the brain. The definite diagnosis still requires histopathological conformation according to the criteria, however, in recent years substantial progress has been made in the area of early biomarker development. The use of cerebrospinal fluid as a testing platform is very promising because the CSF protein composition can reflect the pathological processes of the brain and because it is easily accessible by a lumbar puncture. Some proteins and peptides such as $B$-amyloid 1-42 (A $\beta 1$ 42), $B$-amyloid 1-40 (A $\beta 1-40)$, total tau (tau) and hyperphosphorylated tau ( $\mathrm{p}$-tau) have been reported to meet the criteria for a biomarker. Another series of publications reported transthyretin, isoprostane, BACE1 activity and other proteins and enzymes as a potential biomarkers in AD. Whereas the biomarkers mentioned first have been studied extensively and were suggested to be included into clinical AD criteria, less information is available on the others. This review will focus on the importance of CSF based biomarkers in AD, covers the data available from the literature and highlights their role in the differential diagnosis of dementia.

\section{Why to use CSF as a testing platform in dementia? - Neuroanatomy driven approach}

Cerebrospinal fluid (CSF) is the main component of the brain extracellular space and participates in the exchange of many biochemical products in the central nervous system (CNS). Consequently, CSF contains a dynamic and complex mixture of proteins, which reflects physiological or pathological state of CNS. Changes in CSF proteome have been described in various neurodegenerative disorders. These alterations are discussed to reflect pathological changes in the brain and thus contribute to a better understanding of the pathophysiology of the underlying disorder (Gawinecka et al. 2010).

CSF analysis is extremely important to identify autoimmune disorders and inflammatory conditions, which might lead to dementia. Although changes are non-specific, like 
pleocytosis, elevated protein content, increased albumin ratio and oligoclonal IgG synthesis within the central nervous system, their presence clearly differentiate inflammatory and autoimmune disease from neurodegenerative dementia.

\section{How to select a biomarker - a concept-of-pathogenesis-driven approach}

Several potential biomarkers in the CSF and blood have been already suggested. Some of them like $A \beta 1-42$ and tau (and its phosphorylated form) became important biomarker in dementia diagnosis. The advantage of these biomarkers is their clear link to the pathological process and abnormalities, which are detected in the brain of AD patients (Aß and amyloid hypothesis as well as tau pathology).

\subsection{Amyloid hypothesis}

The amyloid core of senile or neuritic plaques contains an amyloid-like substance formed by peptides, which originate from proteolytic cleavage of the membrane-associated precursor protein (amyloid precursor protein, APP). They are generated by a sequential cleavage of amyloid precursor protein (APP) by $\beta$ - and $\gamma$-secretase. $A \beta$ s are small hydrophobic peptides existing mainly in two lengths: $A \beta 1-40$ and $A \beta 1-42$. It was initially assumed that the production of $A \beta$ s occurs only under pathological conditions. Later, $A \beta$ was shown to be constitutively released from APP and secreted to blood and CSF. In AD, A $\beta$ peptides are involved in pathological processes and accumulate in the brain as amyloid or senile plaques. There is clear correlation between A $\beta$ levels in CSF and plaque depositions in the brain coupled with the concept of casual involvement of APP and A $\beta$ s in the pathogenesis of AD. The concentration of $A \beta s$ is thought to reflect disease-associated changes and is widely applied as a diagnostic biomarker of AD (Gawinecka et al. 2010).

Table 1 gives an overview of publications related to this topic from past 5 years. The vast majority of publications is related to the detection of abnormal levels of Aß1-42 in AD as compared to other dementia, however, some data are also available for Aß1-40. Recently, a ratio between both peptides has been suggested as a potential biomarker in AD (Table 2). Aß1-42 level is decreased in patients with AD, but might also decrease in other dementia, too. Test sensitivity for Aß1-42 alone is given from 60 to $96 \%$, depending on the design of the study.

In MCI, Aß42 level is lower in patients with a subsequent AD diagnosis (De Meyer et al. 2010; Diniz et al. 2008; Mattsson et al. 2009; Stefani et al. 2006), which leads to the conclusion that this parameter might also serve as an preclinical (potential predictive?) biomarker (Stefani et al. 2006) for cognitive decline.

Aß42 level is decreased in other conditions, including prion diseases, Parkinson's disease (Siderowf et al. 2010) and DLB. In PD, decreased levels correlate well with cognitive decline, in contrast to tau/p-tau ratio (see below) (Siderowf et al. 2010). According to some studies which used patients with non-AD dementia as controls, this marker is highly sensitive for detection of dementia, but it seems that it does not allow to discriminate between various dementia types because of limited specificity (Formichi et al. 2006; Gloeckner et al. 2008).

One approach to improve test sensitivity and specificity was to calculate an Aß42/40 ratio, which is significantly decreased in AD patients. It seems also to discriminate between different dementia including $\mathrm{AD}$ and non-AD (vascular, mixed, FTD, alcohol toxic and controls) (Lewczuk et al. 2004). However, the significance of this finding has still to be proven on higher numbers of patients in a prospective study. 


\begin{tabular}{|c|c|c|c|c|}
\hline & Patients (n) & Sensitivity (\%) & Specificity (\%) & Reference \\
\hline$A ß 1-42$ & $\begin{array}{l}\text { MCI -> AD (422) } \\
\text { controls (429) }\end{array}$ & 68 & 93 & (Diniz et al. 2008) \\
\hline $\mathrm{AB} 1-42$ & $\begin{array}{l}\text { PD (109) } \\
\text { AD (20) } \\
\text { controls (36) }\end{array}$ & & ว.a. & (Alves et al. 2010) \\
\hline$A ß 1-42$ & $\begin{array}{l}\text { AD (131) } \\
\text { controls (72) }\end{array}$ & 92 & 89 & $\begin{array}{l}\text { (Sunderland et al. } \\
\text { 2003) }\end{array}$ \\
\hline $\mathrm{Aß} 1-42$ & PD (45) & & ว.a. & $\begin{array}{l}\text { (Siderowf et al. } \\
2010)\end{array}$ \\
\hline Aß1-42 & $\mathrm{MCI}$ & & 1.a. & $\begin{array}{l}\text { (Okonkwo et al. } \\
2011)\end{array}$ \\
\hline $\mathrm{Aß} 1-42$ & $\begin{array}{l}\mathrm{AD}(33) \\
\mathrm{ARCD}^{*}(20) \\
\text { controls (50) }\end{array}$ & $70-84$ & $80-85$ & $\begin{array}{l}\text { (Kapaki et al. } \\
2005)\end{array}$ \\
\hline Aß1-42 & $\begin{array}{l}\text { MCI (750) } \\
\text { AD (529) } \\
\text { controls (304) }\end{array}$ & 79 & 65 & $\begin{array}{l}\text { (Mattsson et al. } \\
\text { 2009) }\end{array}$ \\
\hline Aß1-42 & $\begin{array}{l}\text { autoptic AD (68) } \\
\text { MCI (57) }\end{array}$ & 94 & n.a. & $\begin{array}{l}\text { (De Meyer et al. } \\
2010 \text { ) }\end{array}$ \\
\hline Aß1-42 & $A D$ & $>85$ & $>85$ & (Slats et al. 2010) \\
\hline Aß1-42 & $\begin{array}{l}\text { mild AD (100) } \\
\text { MCI (196) } \\
\text { controls (114) }\end{array}$ & 96 & 77 & (Shaw et al. 2009) \\
\hline$A ß 1-40$ & $\begin{array}{l}\mathrm{AD}(82) \\
\mathrm{DLB}(44) \\
\text { controls (71) }\end{array}$ & $\begin{array}{l}\text { AD vs controls } \\
97\end{array}$ & $\begin{array}{l}\text { AD vs controls } \\
83\end{array}$ & $\begin{array}{l}\text { (Mollenhauer et } \\
\text { al. 2011) }\end{array}$ \\
\hline$A ß 1-40$ & $\begin{array}{l}\operatorname{DLB}(21) \\
\operatorname{AD}(23) \\
\operatorname{PDD}(21)\end{array}$ & 81 & 71 & (Bibl et al. 2006a) \\
\hline Aß1-40 & $\begin{array}{l}\text { AD (23) } \\
\text { NPH (13) } \\
\text { DLB (23) } \\
\text { CJD (18) } \\
\text { DLB (23) } \\
\text { FTD (10) } \\
\text { controls (19) }\end{array}$ & 61 & 78 & $\begin{array}{l}\text { (Gloeckner et al. } \\
2008)\end{array}$ \\
\hline
\end{tabular}

${ }^{*} \mathrm{ARCD}=$ alcohol related cognitive disorder

Table 1. Aß40 and Aß42 in dementia diagnosis 


\begin{tabular}{|l|l|l|l|l|}
\hline & Diagnosis (n) & \multicolumn{1}{|c|}{ Sensitivity (\%) } & \multicolumn{1}{|c|}{ Specificity (\%) } & \multicolumn{1}{c|}{ Reference } \\
\hline $\begin{array}{l}\text { Aß1-42/ } \\
\text { Aß1-40 }\end{array}$ & MCI (65) & 86 & 60 & (Brys et al. 2009) \\
\hline $\begin{array}{l}\text { Aß1-42/ } \\
\text { Aß1-40 }\end{array}$ & AD (22) & 95 & 88 & $\begin{array}{l}\text { (Lewczuk et al. } \\
2004)\end{array}$ \\
\hline $\begin{array}{l}\text { Aß1-42/ } \\
\text { Aß1-40 }\end{array}$ & AD (157) & 59 & 88 & $\begin{array}{l}\text { (Shoji and Kanai } \\
2001)\end{array}$ \\
\hline $\begin{array}{l}\text { Aß1-42/ } \\
\text { Aß1-40 }\end{array}$ & AD (69) & & & (Spies et al. 2010) \\
\hline $\begin{array}{l}\text { Aß1-42/ } \\
\text { Aß1-40 }\end{array}$ & AD (18) & $\begin{array}{l}\text { AD vs control: } 100 \\
\text { AD vs DLB: } 100\end{array}$ & $\begin{array}{l}\text { AD vs control: } 93 \\
\text { AD vs DLB: } 68\end{array}$ & (Bibl et al. 2006b) \\
AD vs both groups: & AD vs both groups: 77 & \\
\hline $\begin{array}{l}\text { Aß1-42/ } \\
\text { Aß1-40 }\end{array}$ & AD (109) & $\begin{array}{l}\text { AD vs control: 79 } \\
\text { AD vs all: 70 }\end{array}$ & $\begin{array}{l}\text { AD vs control: 71 } \\
\text { AD vs all: 71 }\end{array}$ & $\begin{array}{l}\text { (Brettschneider et } \\
\text { al. 2006) }\end{array}$ \\
\hline
\end{tabular}

Table 2. Aß1-42/ Aß1-40 ratio as potential biomarkers in $\mathrm{AD}$

\subsection{Tau hypothesis}

Intracellular neurofibrillary tangles (NFT), which are neuronal inclusions consisting of abnormal cytoskeletal elements of hyperphosphorylated tau protein are another characteristic pathological feature of AD. These tangles are found throughout the neocortex, in the nucleus basalis Meynert, thalamus, and in the mammillary bodies. Tau protein is a microtubule-associated protein (MAP), which interacts with tubulin and promotes microtubule assembly and stability; it is also involved in neurogenesis, axonal maintenance and axonal transport. There are six different tau isoforms present in the human adult brain, which are generated by an alternative mRNA splicing from a single gene (Goedert et al. 1989). Tau is a phosphoprotein, with 79 putative serine or threonine phosphorylation sites on the longest tau isoform. The hyperphosphorylated tau has a reduced affinity for microtubules and reduced ability to promote their assembly (Lindwall and Cole 1984). In $\mathrm{AD}$, tau detaches from microtubules and aggregates in paired helical filaments (PHFs). Tau isolated from these aggregates is found to be about 4 times more phoshorylated than tau isolated from nondemented individuals (Alonso et al. 2001; Kopke et al. 1993, Gawinecka and Zerr 2010).

The elevated CSF level of nonphosphorylated and phosphorylated tau is one of AD hallmarks (Andreasen et al. 1999; Arai et al. 1997; Galasko et al. 1997; Ishiguro et al. 1999; Itoh et al. 2001; Mecocci et al. 1998). Since the first description of this abnormality and availability of an ELISA test, extensive research has been conducted. Data on tau level in AD and other dementia are given in Table 3. Again, elevated levels can be observed in other conditions than AD too, the test sensitivity and specificity seems to be above $80 \%$ in majority of the cases (Table 3). However, it has to be kept in mind that tau levels increase in CSF with age and this physiological finding hast to be kept in mind when cut-off level are established (Figure 1). In pathological conditions, total tau levels in MCI patients indicate increased AD risk (Hertze et al. 2010; Mattsson et al. 2009; Pauwels et al. 2009) and increased level correlates well with disease severity (Buchhave et al. 2009; Stefani et al. 2006). Some studies even demonstrated that extremely high tau levels might be indicator of poor prognosis (Snider et al. 2009). 


\begin{tabular}{|c|c|c|c|}
\hline Patients (n) & Sensitivity (\%) & Specificity (\%) & Reference \\
\hline MCI (166) & 78 & 83 & (Hertze et al. 2010) \\
\hline $\mathrm{AD}(131)$ & 92 & 89 & (Sunderland et al. 2003) \\
\hline $\begin{array}{l}\text { AD, CJD, LBD, } \\
\text { FTD, VD }\end{array}$ & $73-91$ & $74-98$ & (van Harten et al. 2011) \\
\hline $\begin{array}{l}\mathrm{AD}(33) \\
\operatorname{ARCD}^{*}(20)\end{array}$ & $88-94$ & $95-96$ & (Kapaki et al. 2005) \\
\hline $\begin{array}{l}\mathrm{AD} \\
\mathrm{NPH}\end{array}$ & $91-93$ & $78-96$ & (Kapaki et al. 2007) \\
\hline $\begin{array}{l}\text { MCI (750) } \\
\text { AD (529) }\end{array}$ & 86 & 56 & (Mattsson et al. 2009) \\
\hline $\begin{array}{l}\text { AD, other } \\
\text { dementia, } \\
\text { psychiatric (219) }\end{array}$ & 88 & 80 & (Ibach et al. 2006) \\
\hline $\begin{array}{l}\text { early AD (269) } \\
\text { mild AD (468) } \\
\text { late AD (495) }\end{array}$ & n.a. & & (Stefani et al. 2006) \\
\hline $\mathrm{MCI}->\mathrm{AD}$ & 82 & 87 & (Pauwels et al. 2009) \\
\hline $\begin{array}{l}\text { mild AD (100) } \\
\text { MCI (192) } \\
\text { autoptic AD (56) } \\
\text { controls (114) }\end{array}$ & 70 & 92 & (Shaw et al. 2009) \\
\hline $\begin{array}{l}\text { MCI -> AD (422) } \\
\text { controls (420) }\end{array}$ & 68 & 93 & (Diniz et al. 2008) \\
\hline $\begin{array}{l}\text { DLB (34) } \\
\text { AD (31) } \\
\text { other dementia (4) }\end{array}$ & 85 & 95 & (Kasuga et al. 2010) \\
\hline
\end{tabular}

*ARCD $=$ alcohol related cognitive disorder

Table 3. Total tau level in cerebrospinal fluid in AD and other dementia

Regarding phosphorylated tau level in CSF, a recent metaanalysis on 51 publications from the area revealed that $\mathrm{p}$-tau contributed to the separation of $\mathrm{MCI}$ from healthy individuals with a sensitivity of $80 \%$ and specificity of $84 \%$ (Mitchell 2009). CSF p-tau is a good diagnostic biomarker of $\mathrm{AD}$ too, with test sensitivity mostly $>80 \%$ (see Table 4). MCI patients with low Aß1-42 and high p-tau levels are at a clear AD risk (Hertze et al. 2010). AD patients with higher p-tau level have greater hippocampal atrophy, poorer neuropsychological test results and it is also indicator of disease progression (Henneman et al. 2009). Whereas p-tau levels indicate AD or development of AD with good accuracy, unfortunately, this biomarker is also less adequate in separating AD from other dementias (Mitchell 2009).

Due to these considerations, several studies tried to analyse the diagnostic potential of ptau/total tau ratio. Some of them reported test sensitivity between $88-96 \%$ with a specificity of $60-100 \%$. While its ratio is promising, again, it has to be analysed in a prospective setting since the numbers of analysed patients so far are too low for any definite conclusions (Buerger et al. 2006; Hu et al. 2002; Kapaki et al. 2007). 


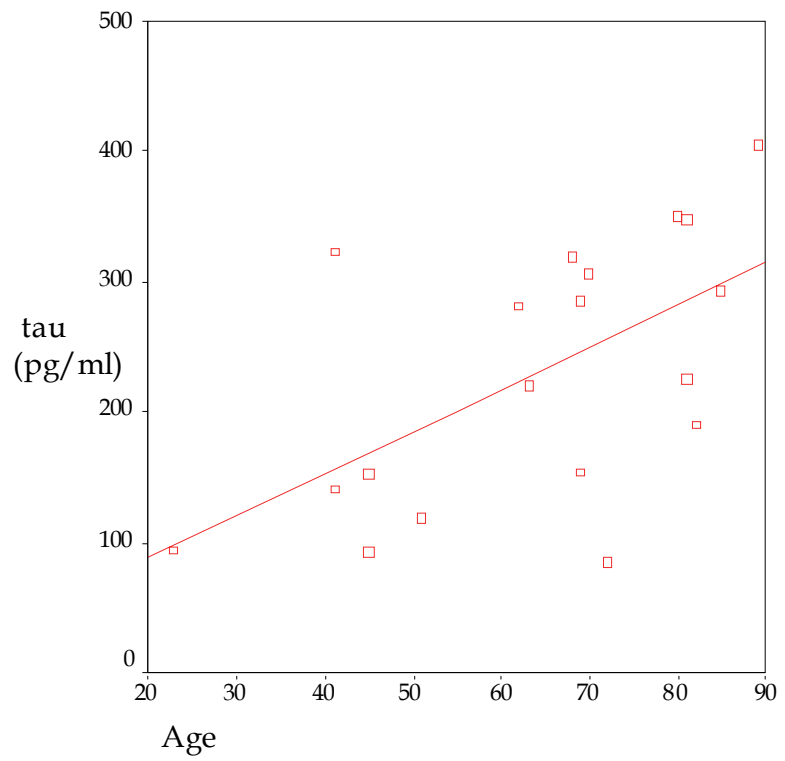

Fig. 1. Total tau level in cerebrospinal fluid stratified by age in healthy controls (Gloeckner et al. 2008)

\begin{tabular}{|c|c|c|c|c|}
\hline & Patients (n) & Sensitivity (\%) & Specificity (\%) & Reference \\
\hline p-tau & $\begin{array}{l}\text { AD } \\
\text { neurological } \\
\text { controls (46) }\end{array}$ & $>85$ & $79-91$ & $\begin{array}{l}\text { (Scheurich et } \\
\text { al. 2010) }\end{array}$ \\
\hline p-tau & \begin{tabular}{|l|} 
AD (94) \\
MCI (166) \\
depression (29) \\
controls (38) \\
\end{tabular} & $>85$ & $79-91$ & $\begin{array}{l}\text { (Hertze et al. } \\
2010)\end{array}$ \\
\hline p-tau & AD (49) & 46 & 94 & \begin{tabular}{|l} 
(Snider et al. \\
$2009)$
\end{tabular} \\
\hline p-tau & $\begin{array}{l}\text { AD (251) } \\
\text { controls (122) }\end{array}$ & 62 & 93 & $\begin{array}{l}\text { (Formichi et al. } \\
2006 \text { ) }\end{array}$ \\
\hline p-tau & $\begin{array}{l}\text { AD, CJD, LBD, } \\
\text { FTD, vascular } \\
\text { dementia }\end{array}$ & $79-88$ & $78-83$ & $\begin{array}{l}\text { (van Harten et } \\
\text { al. 2011) }\end{array}$ \\
\hline p-tau & $\mathrm{AD}, \mathrm{NPH}$, controls & 89 & 87 & $\begin{array}{l}\text { (Kapaki et al. } \\
\text { 2007) }\end{array}$ \\
\hline p-tau & $\begin{array}{l}\text { AD, other } \\
\text { dementia, } \\
\text { psychiatric, } \\
\text { controls }\end{array}$ & 89 & 87 & $\begin{array}{l}\text { (Ibach et al. } \\
2006)\end{array}$ \\
\hline p-tau & $\begin{array}{l}\mathrm{AD}(31) \\
\mathrm{MCI}(25)\end{array}$ & $72-81$ & $78-88$ & $\begin{array}{l}\text { (Henneman et } \\
\text { al. 2009) }\end{array}$ \\
\hline
\end{tabular}




\begin{tabular}{|c|c|c|c|c|}
\hline & Patients (n) & Sensitivity (\%) & Specificity (\%) & Reference \\
\hline$p$-tau & $\begin{array}{l}\text { autoptic AD (68) } \\
\text { MCI (57) }\end{array}$ & $\begin{array}{l}\text { AD 94 } \\
\text { MCI 100 }\end{array}$ & & $\begin{array}{l}\text { (De Meyer et } \\
\text { al. 2010) }\end{array}$ \\
\hline p-tau & $\begin{array}{l}\text { mild AD (100) } \\
\text { MCI (196) } \\
\text { autoptic AD (56) } \\
\text { controls (114) }\end{array}$ & 68 & 73 & $\begin{array}{l}\text { (Shaw et al. } \\
2009)\end{array}$ \\
\hline p-tau & $\begin{array}{l}\text { MCI (750) } \\
\text { AD (529) } \\
\text { Controls (304) } \\
\end{array}$ & 84 & 47 & $\begin{array}{l}\text { (Mattsson et al. } \\
\text { 2009) }\end{array}$ \\
\hline $\mathrm{p}$-tau/total tau & $\begin{array}{l}\text { AD (52) } \\
\text { controls (56) } \\
\text { non AD (37) } \\
\text { vascular dementia } \\
(46) \\
\end{array}$ & 96 & 94 & (Hu et al. 2002) \\
\hline $\mathrm{p}$-tau/total tau & $\begin{array}{l}\mathrm{AD}(67) \\
\mathrm{NPH}(18) \\
\text { controls (72) }\end{array}$ & $88-93$ & $60-100$ & $\begin{array}{l}\text { (Kapaki et al. } \\
\text { 2007) }\end{array}$ \\
\hline $\mathrm{p}$-tau/total tau & $\begin{array}{l}\text { AD (37) } \\
\text { CJD (21) } \\
\text { controls (10) }\end{array}$ & 91 & 97 & $\begin{array}{l}\text { (Buerger et al. } \\
2006)\end{array}$ \\
\hline $\mathrm{p}$-tau/total tau & $\begin{array}{l}\text { AD (71) } \\
\text { FTD (18) } \\
\text { CJD (20) } \\
\text { controls (43) }\end{array}$ & $\begin{array}{l}\text { ratio AD: 1,27 }(\mathrm{m} \\
\text { ratio FTD: } 1,13(\mathrm{n} \\
\text { ratio CJD: } 0,05(\mathrm{~m} \\
\text { ratio controls: } 1,7\end{array}$ & $\begin{array}{l}\text { an) } \\
\text { ean) } \\
\text { ean) } \\
\text { (mean) }\end{array}$ & $\begin{array}{l}\text { (Riemenschnei } \\
\text { der et al. 2003) }\end{array}$ \\
\hline $\mathrm{p}$-tau/total tau & $\begin{array}{l}\text { CJD (21) } \\
\text { AD (49) } \\
\text { neurol. controls } \\
(164)\end{array}$ & 86 & 90 & $\begin{array}{l}\text { (Bahl et al. } \\
2009)\end{array}$ \\
\hline
\end{tabular}

Table 4. Phosphorylated tau level in cerebrospinal fluid in AD and other dementia

In general, many studies on Aß1-42, total tau level and its phosphorylated isoform have been performed. In most studies, the number of patients per group is limited and various criteria and diagnostic techniques have been applied. Of importance, a recent multicenter study demonstrated once again that CSF Aß1-42, total tau and p-tau identify incipient AD with good sensitivity and specificity, however, the data are less reliable than reported from single-center studies (Mattsson et al. 2009). Thus, improvements are necessary, with respect to standardisation protocols between centers, but also with respect to identification of further disease- specific biomarkers in biological fluids.

\subsection{The role of ApoE}

The presence of the apolipoprotein E allele is a well documented risk factor for AD (Lamb et al. 1998; Saunders et al. 1993) and is associated with a decreased age of clinical onset, with a higher stage of $B$-amyloid deposition and neurofibrillary change formation, severe disease course, higher brain atrophy and a more rapid disease course (Ohm et al. 1999). The ApoE polymorphism includes three common alleles $(\varepsilon 2, \varepsilon 3, \varepsilon 4)$ at a single gene locus resulting in 
six ApoE genotypes $\varepsilon 2 / \varepsilon 2, \varepsilon 3 / \varepsilon 3, \varepsilon 4 / \varepsilon 4, \varepsilon 2 / \varepsilon 3, \varepsilon 2 / \varepsilon 4, \varepsilon 3 / \varepsilon 4$. The ApoE $\varepsilon 4$ allele is an established risk factor for AD (Saunders et al. 1993) and there is a large body of evidence for a role of ApoE in the pathogenesis of AD (Davidson et al. 2006; Varges et al. 2011).

\begin{tabular}{|c|c|c|c|}
\hline CSF marker & $\begin{array}{l}\text { Patients (n) } \\
\text { [diagnosis } \\
\text { confirmed] }\end{array}$ & Influence of ApoE $\varepsilon 4$ allele & Reference \\
\hline$A ß 1-42$ & \multirow[t]{2}{*}{82} & dose-dependent reduction & \multirow[t]{2}{*}{ (Galasko et al. 1998) } \\
\hline tau & & $\begin{array}{l}\text { heterozygous: elevation } \\
\text { homozygous: reduction }\end{array}$ & \\
\hline $\mathrm{A} ß 1-42$ & 50 & dose-dependent reduction & $\begin{array}{l}\text { (Riemenschneider et al. } \\
2000)\end{array}$ \\
\hline Aß1-42 & 84 & dose-dependent reduction & (Hulstaert et al. 1999) \\
\hline $\mathrm{AB} 1-42$ & \multirow[t]{2}{*}{73} & $\begin{array}{l}\text { more reduced levels in } \varepsilon 4 \\
\text { carriers }\end{array}$ & \multirow[t]{2}{*}{ (Smach et al. 2008) } \\
\hline tau & & no influence & \\
\hline Aß1-42 & 60 & no influence & (Ewers et al. 2008) \\
\hline $\mathrm{A} ß 1-42$ & 50 & no influence & \multirow[t]{2}{*}{ (Engelborghs et al. 2007) } \\
\hline tau & & no influence & \\
\hline tau & 19 & dose-dependent elevation & (Golombowski et al. 1997) \\
\hline$A ß 1-42$ & \multirow[t]{2}{*}{$121[41 \mathrm{NP}]$} & $\begin{array}{l}\text { more reduced levels in } \varepsilon 4 \\
\text { carriers }\end{array}$ & \multirow[t]{2}{*}{ (Tapiola et al. 2000) } \\
\hline tau & & $\begin{array}{l}\text { more elevated levels in } \varepsilon 4 \\
\text { carriers }\end{array}$ & \\
\hline Aß1-42 & 563 & $\begin{array}{l}\text { more reduced levels in } \varepsilon 4 \\
\text { carriers }\end{array}$ & (Prince et al. 2004) \\
\hline $\mathrm{A} ß 1-42$ & 150 & $\begin{array}{l}\text { more reduced levels in } \varepsilon 4 \\
\text { carriers }\end{array}$ & (Sunderland et al. 2004) \\
\hline
\end{tabular}

Table 5. Influence of the ApoE $\varepsilon 4$ allele on CSF markers in AD (modified from Varges et al. 2011)

The ApoE $\varepsilon 4$ allele status is important to be analysed in the context of CSF biomarker. Some studies report no association between ApoE $\varepsilon 4$ allele and tau level, whereas others show higher tau level among ApoE $\varepsilon 4$ carriers when compared to non-carriers among AD patients. The situation seems to be clearer for $B$-amyloid 1-42: several studies report correlations between Aß1-42 levels and the ApoE $\varepsilon 4$ allele (Table 5) (modified from Varges et al. 2011). Although the pathological links are not clearly identify at the moment, it is apparent that the ApoE genotype has to be taken into consideration. 


\section{Clinical criteria for $A D$}

CSF biomarkers play an important role in clinical diagnosis and differential diagnosis of neurodegenerative dementia. A lot of research in this area has been already conducted. Recently, these markers which are associated with disease pathology in the brain namely Aß1-42 as a parameter of the amyloid cascade and tau and its phosphorylated isoforms have been suggested to be included into diagnostic criteria for AD. The typical AD signature comprises low CSF Aß1-42 levels and high total tau/p-tau level and it was suggested as a parameter of one of the supportive features at the same level as structural and functional brain imaging for probable AD diagnosis (Dubois et al. 2007).

\section{Conclusions}

The PubMed search on 31.1.2011 using keywords cerebrospinal fluid and Alzheimer reveals 2336 hits. Although not all are dealing directly with biomarker discovery and identification of novel proteins for diagnosis, they are linked to the topic and demonstrate once again the importance of the area. Adequate biomarker, which can be easily analysed in CSF and, even better, blood, will have a great potential for clinical and also preclinical diagnosis of the disease. In neurodegenerative disorders, we have to meet the problem of early disease diagnosis, because it is likely that neuroprotective and other pharmacological strategies will allow better treatment response in earlier disease stages.

\section{Acknowledgements}

This manuscript is supported by the BMBF grant within German Network for Degenerative Dementia, KNDD-2, 2011-2013, Determinants for disease progression in AD

\section{References}

Alonso A, Zaidi T, Novak M, Grundke-Iqbal I, Iqbal K. 2001. Hyperphosphorylation induces self-assembly of tau into tangles of paired helical filaments/straight filaments. Proc Natl Acad Sci U S A 98(12):6923-6928.

Alves G, Bronnick K, Aarsland D, Blennow K, Zetterberg H, Ballard C et al. 2010. CSF amyloid-beta and tau proteins, and cognitive performance, in early and untreated Parkinson's disease: the Norwegian ParkWest study. J Neurol Neurosurg Psychiatry 81(10):1080-1086.

Andreasen N, Minthon L, Clarberg A, Davidsson P, Gottfries J, Vanmechelen E et al. 1999. Sensitivity, specificity, and stability of CSF-tau in AD in a community-based patient sample. Neurology 53(7):1488-1494.

Arai H, Morikawa Y, Higuchi M, Matsui T, Clark CM, Miura M et al. 1997. Cerebrospinal fluid tau levels in neurodegenerative diseases with distinct tau-related pathology. Biochem Biophys Res Commun 236:262-264.

Bahl JM, Heegaard NH, Falkenhorst G, Laursen H, Hogenhaven H, Molbak K et al. 2009. The diagnostic efficiency of biomarkers in sporadic Creutzfeldt-Jakob disease compared to Alzheimer's disease. Neurobiol Aging 30(11):1834-1841. 
Bibl M, Mollenhauer B, Esselmann H, Lewczuk P, Klafki HW, Sparbier K et al. 2006a. CSF amyloid-beta-peptides in Alzheimer's disease, dementia with Lewy bodies and Parkinson's disease dementia. Brain 129(Pt 5):1177-1187.

Bibl M, Mollenhauer B, Esselmann H, Lewczuk P, Trenkwalder C, Brechlin P et al. 2006b. CSF diagnosis of Alzheimer's disease and dementia of Lewy bodies. J Neural Transm 113(11):1771-1778.

Brettschneider J, Petzold A, Schottle D, Claus A, Riepe M, Tumani H. 2006. The neurofilament heavy chain $(\mathrm{NfH})$ in the cerebrospinal fluid diagnosis of Alzheimer's disease. Dement Geriatr Cogn Disord 21(5-6):291-295.

Brys M, Pirraglia E, Rich K, Rolstad S, Mosconi L, Switalski R et al. 2009. Prediction and longitudinal study of CSF biomarkers in mild cognitive impairment. Neurobiol Aging 30(5):682-690.

Buchhave P, Blennow K, Zetterberg H, Stomrud E, Londos E, Andreasen N et al. 2009. Longitudinal study of CSF biomarkers in patients with Alzheimer's disease. PLoS One 4(7):e6294.

Buerger K, Otto M, Teipel SJ, Zinkowski R, Blennow K, DeBernardis J et al. 2006. Dissociation between CSF total tau and tau protein phosphorylated at threonine 231 in Creutzfedt-Jakob disease. Neurobiol Aging 27(1):10-15.

Davidson Y, Gibbons L, Purandare N, Byrne J, Hardicre J, Wren J et al. 2006. Apolipoprotein E epsilon4 allele frequency in vascular dementia. Dementia and Geriatric Cognitive Disorders 22(1):15-19.

De Meyer G, Shapiro F, Vanderstichele H, Vanmechelen E, Engelborghs S, De Deyn PP et al. 2010. Diagnosis-independent Alzheimer disease biomarker signature in cognitively normal elderly people. Arch Neurol 67(8):949-956.

Diniz BS, Pinto Junior JA, Forlenza OV. 2008. Do CSF total tau, phosphorylated tau, and beta-amyloid 42 help to predict progression of mild cognitive impairment to Alzheimer's disease? A systematic review and meta-analysis of the literature. World J Biol Psychiatry 9(3):172-182.

Dubois B, Feldman HH, Jacova C, DeKosky ST, Barberger-Gateau P, Cummings J et al. 2007. Research criteria for the diagnosis of Alzheimer's disease: revising the NINCDSADRDA criteria. Lancet Neurol 6:734-746.

Engelborghs S, Sleegers K, Cras P. 2007. No association of CSF biomarkers with APOEepsilon4, plaque and tangle burden in definite Alzheimer's disease. Brain 130:2320-2326.

Ewers M, Zhong Z, Buerger K. 2008. Increased CSF BACE 1 activity is associated with ApoE-epsilon 4 genotype in subjects with mild cognitive impairment and Alzheimer's disease. Brain 131:1252-1258.

Battisti C, Radi E, Federico A. 2006. Cerebrospinal fluid tau, A beta, and phosphorylated tau protein for the diagnosis of Alzheimer's disease. 208(1):39-46.

Galasko D, Chang L, Motter R. 1998. High cerebrospinal fluid tau and low amyloid beta42 levels in the clinical diagnosis of Alzheimer disease and relation to apolipoprotein E genotype. Arch Neurol 55:937-945. 
Galasko D, Clark C, Chang L, Miller B, Green RC, Motter R et al. 1997. Assessment of CSF levels of tau protein in mildly demented patients with Alzheimer's disease. Neurology 48(3):632-635.

Gawinecka J, Zerr I. 2010. Cerebrospinal fluid biomarkers in human prion diseases. Future Neurol. 5(2):301-316.

Gloeckner SF, Meyne F, Wagner F, Heinemann U, Krasnianski A, Meissner B et al. 2008. Quantitative analysis of transthyretin, tau and amyloid-beta in patients with dementia. J Alzheimers Dis 14(1):17-25.

Goedert M, Spillantini MG, Potier MC, Ulrich J, Crowther RA. 1989. Cloning and sequencing of the cDNA encoding an isoform of microtubule-associated protein tau containing four tandem repeats: differential expression of tau protein mRNAs in human brain. Embo J 8(2):393-399.

Golombowski S, Mueller-Spahn F, Romig H. 1997. Dependence of cerebrospinal fluid Tau protein levels on apolipoprotein E4 allele frequency in patients with Alzheimer's disease. Neurosci Lett 225:213-215.

Henneman WJ, Vrenken H, Barnes J, Sluimer IC, Verwey NA, Blankenstein MA et al. 2009. Baseline CSF p-tau levels independently predict progression of hippocampal atrophy in Alzheimer disease. Neurology 73(12):935-940.

Hertze J, Minthon L, Zetterberg H, Vanmechelen E, Blennow K, Hansson O. 2010. Evaluation of CSF biomarkers as predictors of Alzheimer's disease: a clinical follow-up study of 4.7 years. J Alzheimers Dis 21(4):1119-1128.

$\mathrm{Hu}$ YY, He SS, Wang X, Duan QH, Grundke-Iqbal I, Iqbal K et al. 2002. Levels of nonphosphorylated and phosphorylated tau in cerebrospinal fluid of Alzheimer's disease patients: an ultrasensitive bienzyme-substrate-recycle enzyme-linked immunosorbent assay. Am J Pathol 160(4):1269-1278.

Hulstaert F, Blennow K, Ivanoiu A, Schoonderwaldt HC, Riemenschneider M, De Deyn PP et al. 1999. Improved discrimination of AD patients using beta-amyloid(1-42) and tau levels in CSF. Neurology 52(8):1555-1562.

Ibach B, Binder H, Dragon M, Poljansky S, Haen E, Schmitz E et al. 2006. Cerebrospinal fluid tau and beta-amyloid in Alzheimer patients, disease controls and an age-matched random sample. Neurobiol Aging 27(9):1202-1211.

Ishiguro K, Ohno H, Arai H, Yamaguchi H, Urakami K, Park JM et al. 1999. Phosphorylated tau in human cerebrospinal fluid is a diagnostic marker for Alzheimer's disease. Neurosci Lett 270(2):91-94.

Itoh N, Arai H, Urakami K, Ishiguro K, Ohno H, Hampel H et al. 2001. Large-scale, multicenter study of cerebrospinal fluid tau protein phosphorylated at serine 199 for the antemortem diagnosis of Alzheimer's disease. Ann Neurol 50(2):150156.

Kapaki E, Liappas I, Paraskevas GP, Theotoka I, Rabavilas A. 2005. The diagnostic value of tau protein, beta-amyloid (1-42) and their ratio for the discrimination of alcoholrelated cognitive disorders from Alzheimer's disease in the early stages. Int J Geriatr Psychiatry 20(8):722-729.

Kapaki EN, Paraskevas GP, Tzerakis NG, Sfagos C, Seretis A, Kararizou E et al. 2007. Cerebrospinal fluid tau, phospho-tau181 and beta-amyloid1-42 in idiopathic 
normal pressure hydrocephalus: a discrimination from Alzheimer's disease. Eur J Neurol 14(2):168-173.

Kasuga K, Tokutake T, Ishikawa A, Uchiyama T, Tokuda T, Onodera O et al. 2010. Differential levels of alpha-synuclein, beta-amyloid42 and tau in CSF between patients with dementia with Lewy bodies and Alzheimer's disease. J Neurol Neurosurg Psychiatry 81(6):608-610.

Kopke E, Tung YC, Shaikh S, Alonso AC, Iqbal K, Grundke-Iqbal I. 1993. Microtubuleassociated protein tau. Abnormal phosphorylation of a non-paired helical filament pool in Alzheimer disease. J Biol Chem 268(32):24374-24384.

Lamb H, Christie J, Singleton AB. 1998. Apolipoprotein E and alpha-1 antichymotrypsin polymorphism genotyping in Alzheimer's disease and in dementia with Lewy bodies. Distinctions between diseases. Neurology 50:388-391.

Lewczuk P, Esselmann H, Otto M, Maler JM, Henkel MK, Eikenberg O et al. 2004. Neurochemical diagnosis of Alzheimer's dementia by CSF Aß 42, Aß 42/ Aß40 ratio and total tau. Neurobiol Aging 25:273-281.

Lindwall G, Cole RD. 1984. Phosphorylation affects the ability of tau protein to promote microtubule assembly. J Biol Chem 259(8):5301-5305.

Mattsson N, Zetterberg H, Hansson O, Andreasen N, Parnetti L, Jonsson M et al. 2009. CSF biomarkers and incipient Alzheimer disease in patients with mild cognitive impairment. Jama 302(4):385-393.

Mecocci P, Cherubini A, Bregnocchi M, Chionne F, Cecchetti R, Lowenthal DT et al. 1998. Tau protein in cerebrospinal fluid: a new diagnostic and prognostic marker in Alzheimer disease? Alzheimer Disease and Associated Disorders 12:211-214.

Mitchell AJ. 2009. CSF phosphorylated tau in the diagnosis and prognosis of mild cognitive impairment and Alzheimer's disease: a meta-analysis of 51 studies. J Neurol Neurosurg Psychiatry 80(9):966-975.

Mollenhauer B, Esselmann H, Trenkwalder C, Schulz-Schaeffer W, Kretzschmar H, Otto $\mathrm{M}$ et al. 2011. CSF amyloid-beta peptides in neuropathologically diagnosed dementia with Lewy bodies and Alzheimer's Disease. J Alzheimers Dis 24(2):383-391.

Okonkwo OC, Mielke MM, Griffith HR, Moghekar AR, O'Brien RJ, Shaw LM et al. 2011. Cerebrospinal fluid profiles and prospective course and outcome in patients with amnestic mild cognitive impairment. Arch Neurol 68(1):113-119.

Pauwels EK, Volterrani D, Mariani G. 2009. Biomarkers for Alzheimer's disease. Drug News Perspect 22(3):151-160.

Prince JA, Zetterberg H, Andreasen N. 2004. APOE E4 allele is associated with reduced cerebrospinal fluid levels of Aß42. Neurology 62:2116-2118.

Riemenschneider M, Schmolke M, Lautenschlager. 2000. Cerebrospinal beta-amyloid (1-42) in early Alzheimer's disease: association with apolipoprotein $\mathrm{E}$ genotype and cognitive decline. Neurosci Lett 284:85-88.

Riemenschneider M, Wagenpfeil S, Vanderstichele H, Otto M, Wiltfang J, Kretzschmar $\mathrm{H}$ et al. 2003. Phospho-tau/total tau ration in cerebrospinal fluid discriminates 
Creutzfeldt-Jakob disease from other dementias. Molecular Psychiatry 8:343347.

Saunders AM, Strittmatter WJ, Schmechel DE. 1993. Association of apolipoprotein E allele epsilon 4 with late onset familial and sporadic Alzheimer's disease. Neurology 43:1467-1472.

Scheurich A, Urban PP, Koch-Khoury N, Fellgiebel A. 2010. CSF phospho-tau is independent of age, cognitive status and gender of neurological patients. J Neurol 257(4):609-614.

Shaw LM, Vanderstichele H, Knapik-Czajka M, Clark CM, Aisen PS, Petersen RC et al. 2009. Cerebrospinal fluid biomarker signature in Alzheimer's disease neuroimaging initiative subjects. Ann Neurol 65(4):403-413.

Shoji M, Kanai M. 2001. Cerebrospinal fluid Abeta40 and Abeta42: Natural course and clinical usefulness. J Alzheimers Dis 3(3):313-321.

Siderowf A, Xie SX, Hurtig H, Weintraub D, Duda J, Chen-Plotkin A et al. 2010. CSF amyloid \{beta\} 1-42 predicts cognitive decline in Parkinson disease. Neurology 75(12):1055-1061.

Slats D, Spies PE, Sjogren MJ, Verhey FR, Verbeek MM, Olde Rikkert MG. 2010. Cerebrospinal fluid biomarkers in diagnosing Alzheimer's disease in clinical practice: an illustration with 3 case reports. Case Rep Neurol 2(1):5-11.

Smach MA, Charfeddine B, Lammouchi T. 2008. CSF beta-amyloid 1-42 and tau in Tunisian patients with Alzheimer's disease: the effect of APOE epsilon4 allele. Neurosci Lett 440:145-149.

Snider BJ, Fagan AM, Roe C, Shah AR, Grant EA, Xiong C et al. 2009. Cerebrospinal fluid biomarkers and rate of cognitive decline in very mild dementia of the Alzheimer type. Arch Neurol 66(5):638-645.

Spies PE, Slats D, Sjögren JM, Kremer BP, Verhey FR, Rikkert MG et al. 2010. The cerebrospinal fluid amyloid beta $42 / 40$ ratio in the differentiation of Alzheimer's disease from non-Alzheimer's dementia. Curr Alzheimer Res 7(5):470-476.

Stefani A, Martorana A, Bernardini S, Panella M, Mercati F, Orlacchio A et al. 2006. CSF markers in Alzheimer disease patients are not related to the different degree of cognitive impairment. J Neurol Sci 251(1-2):124-128.

Sunderland T, Linker G, Mirza N, Putnam KT, Friedman DL, Kimmel LH et al. 2003. Decreased beta-amyloid1-42 and increased tau levels in cerebrospinal fluid of patients with Alzheimer disease. Jama 289(16):2094-2103.

Sunderland T, Mirza N, Putnam KT. 2004. Cerebrospinal fluid B-amyloid 1-42 and tau in control subjects at risk for Alzheimer's disease: the effect of ApoE E4 allele. Biol Psychiatry 56:670-676.

Tapiola T, Pirttilä T, Mehta PD. 2000. Relationship between apoE genotype and CSF betaamyloid (1-42) and tau in patients with probable and definite Alzheimer's disease. Neurobiol Aging 21:735-740.

van Harten AC, Kester MI, Visser PJ, Blankenstein MA, Pijnenburg YA, van der Flier WM et al. 2011. Tau and p-tau as CSF biomarkers in dementia: a meta-analysis. Clin Chem Lab Med 49(3):353-366. 
Varges D, Jung K, Gawinecka J, Heinemann U, Schmitz M, von Ahsen N et al. 2011. Amyloid-b 1-42 levels are modified by apolipoprotein E e4 in Creutzfeldt-Jakob disease in a similar manner as in Alzheimer's disease. J Alzheimers Dis 23(4):717726. 


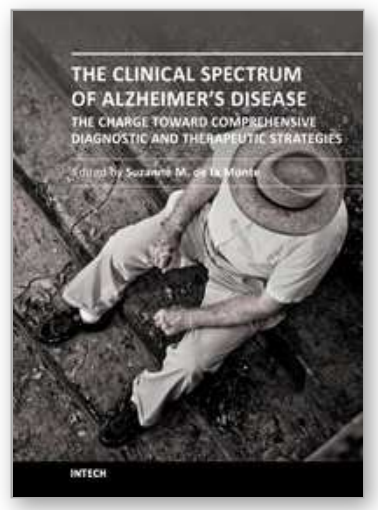

\section{The Clinical Spectrum of Alzheimer's Disease -The Charge Toward Comprehensive Diagnostic and Therapeutic Strategies}

Edited by Dr. Suzanne De La Monte

ISBN 978-953-307-993-6

Hard cover, 362 pages

Publisher InTech

Published online 06, September, 2011

Published in print edition September, 2011

The Clinical Spectrum of Alzheimer's Disease: The Charge Toward Comprehensive Diagnostic and Therapeutic Strategies is highly informative and current. Acknowledged experts in the field critically review both standard and under-appreciated clinical, behavioral, epidemiological, genetic, and neuroimaging attributes of Alzheimer's disease. The collection covers diverse topics of interest to clinicians and researchers alike. Experienced professionals and newcomers to the field will benefit from the read. The strengths and weaknesses of current clinical, non-invasive, neuro-imaging, and biomarker diagnostic approaches are explained. The perspectives give fresh insights into the process of neurodegeneration. Readers will be enlightened by the evidence that the neural circuits damaged by neurodegeneration are much broader than conventionally taught, suggesting that Alzheimer's could be detected at earlier stages of disease by utilizing multi-pronged diagnostic approaches. This book inspires renewed hope that more effective treatments could be developed based upon the expanding list of potential therapeutic targets.

\section{How to reference}

In order to correctly reference this scholarly work, feel free to copy and paste the following:

Inga Zerr, Lisa Kaerst, Joanna Gawinecka and Daniela Varges (2011). Cerebrospinal Fluid Based Diagnosis in Alzheimer's Disease, The Clinical Spectrum of Alzheimer's Disease -The Charge Toward Comprehensive Diagnostic and Therapeutic Strategies, Dr. Suzanne De La Monte (Ed.), ISBN: 978-953-307-993-6, InTech, Available from: http://www.intechopen.com/books/the-clinical-spectrum-of-alzheimer-s-disease-the-chargetoward-comprehensive-diagnostic-and-therapeutic-strategies/cerebrospinal-fluid-based-diagnosis-inalzheimer-s-disease

\section{INTECH}

open science | open minds

\author{
InTech Europe \\ University Campus STeP Ri \\ Slavka Krautzeka 83/A \\ 51000 Rijeka, Croatia \\ Phone: +385 (51) 770447 \\ Fax: +385 (51) 686166 \\ www.intechopen.com
}

\author{
InTech China \\ Unit 405, Office Block, Hotel Equatorial Shanghai \\ No.65, Yan An Road (West), Shanghai, 200040, China \\ 中国上海市延安西路65号上海国际贵都大饭店办公楼405单元 \\ Phone: +86-21-62489820 \\ Fax: +86-21-62489821
}


(C) 2011 The Author(s). Licensee IntechOpen. This chapter is distributed under the terms of the Creative Commons Attribution-NonCommercialShareAlike-3.0 License, which permits use, distribution and reproduction for non-commercial purposes, provided the original is properly cited and derivative works building on this content are distributed under the same license. 